\title{
Relationship between Postoperative Infectious Complications and Glycemic Control for Diabetic Patients in an Orthopedic Hospital in Kuwait
}

\author{
S.M. Lamloum ${ }^{a} \quad$ L.A. Mobasher ${ }^{a}$ A.H. Karar ${ }^{b} \quad$ L. Basiony ${ }^{c}$ T.H. Abdallah ${ }^{d}$ \\ A.I. Al-Saleh ${ }^{a}$ N.A. Al-Shamali ${ }^{a}$ \\ Departments of a Laboratory Medicine, ${ }^{b}$ Medicine, ${ }^{c}$ Preventive Medicine and ${ }^{d}$ Orthopedics, Al Razi Hospital, \\ Ministry of Health, Kuwait
}

\section{Key Words}

Diabetes mellitus $\cdot$ Hemoglobin $A_{1 c} \cdot$ Postoperative infectious complications · Glycemic control

\begin{abstract}
Objective: To study the relationship between postoperative infectious complications and glycemic control for diabetic patients in an orthopedic hospital in Kuwait. Subjects and Methods: Patients who underwent surgical orthopedic procedures between 2006 and 2007 were identified to provide demographic and clinical informations including age, gender, type of surgery, length of operation, $\mathrm{HbA}_{1 c}$ values, nature of specimens and species of the isolated pathogens. $\mathrm{HbA}_{1 \mathrm{c}}<7 \%$ was used as the breaking point for diabetic control and occurrence of postoperative complications. Primary outcomes with infectious complications, including urinary tract infection, surgical site infection (SSI), lower respiratory tract infection and sepsis with different isolated pathogens were identified at least $48 \mathrm{~h}$ postoperatively. Results: Of 318 diabetic patients who underwent surgical operations, 90 (28.3\%) developed postoperative complications; $\mathrm{HbA}_{1 \mathrm{c}}<7 \%$ was significantly associated with decreased infectious complications with an adjusted odds ratio of 2.51 (95\% confidence interval, 1.20-2.89). Regarding types of complications, urinary tract infectious complications were significantly higher among those patients with $\mathrm{HbA}_{1 c} \geq 7 \%(\mathrm{p}<0.0001)$, while other complications (SSI, lower respiratory tract infec-
\end{abstract}

tion and sepsis) showed nonsignificant differences ( $p>0.05$ ). Conclusions: Our study confirmed a close association between preoperative glucose control indicated by $\mathrm{HbA}_{1 c}$ levels $<7 \%$ and a decreased risk of postoperative infectious complications. Ideally, preoperative blood sugar should be controlled prior to elective surgery. Prophylaxis by antibiotics with preoperative patient preparation, proficient surgical technique and postoperative wound care is recommended for uncontrolled diabetics subjected to surgery.

Copyright $\odot 2009$ S. Karger AG, Base

\section{Introduction}

Diabetes mellitus (DM) is a serious public health problem and remains an important cause of morbidity and mortality worldwide [1]. In Kuwait 1996-1998, the overall prevalence of glucose intolerance and non-insulin-dependent DM was 7 and $15.7 \%$, respectively [2]. As DM alters the metabolism of blood sugar, patients with DM are at risk of numerous complications related to microangiopathies and neuropathies [3]. Postoperative infectious complications lead to prolonged hospitalization, poor overall outcomes and high health care costs, particularly for patients with DM for whom the risk of infection is greater and the outcome is worse [4], as reported in a variety of orthopedic procedures [5]. Di Palo et al. [6] demonstrated that diabetic patients had a considerably

\section{KARGER \\ Fax +4161306 1234 \\ E-Mail karger@karger.ch}

www.karger.com
(C) 2009 S. Karger AG, Basel

$1011-7571 / 09 / 0186-0447 \$ 26.00 / 0$

Accessible online at:

www.karger.com/mpp
Dr. S.M. Lamloum

Department of Laboratory Medicine, Al Razi Hospital, Ministry of Health PO Box 13043

Safat 4235 (Kuwait)

Fax +965 2484 3830, E-Mail saharlamlom@yahoo.com 
higher rate of septic complications in clean surgical procedures. Wimmer et al. [7] analyzed 850 patients who underwent spinal procedures and argued that DM was a predisposing factor for infection in spinal surgery. Again, Simpson et al. [8] compared 62 diabetic patients who had posterior decompression surgery with 62 age- and sexmatched nondiabetic patients who had undergone similar procedures. There were high rates of postoperative infection, prolonged hospitalization and poorer postoperative results among the diabetic patients [8].

$\mathrm{HbA}_{1 \mathrm{c}}$ reflects ambient mean glycemia over the previous 2-3 months. Reports indicate that patients with an elevated $\mathrm{HbA}_{1 \mathrm{c}}$ have an increased risk of adverse outcomes following surgical intervention (infection, stroke, adverse cardiac events and mean length of hospital stay) [9]. For diabetic patients, tight control, as measured by percent $\mathrm{HbA}_{1 \mathrm{c}}$, has greatly decreased the incidence and severity of many chronic complications associated directly with diabetes such as nephropathy, neuropathy and retinopathy [10-12].

This study was conducted to determine whether proper preoperative glucose control indicated by $\mathrm{HbA}_{1 \mathrm{c}}$ levels $<7 \%$ was associated with fewer postoperative infections in diabetic patients undergoing a variety of orthopedic surgical procedures.

\section{Subjects and Methods}

\section{Study Design and Data Collection}

This retrospective observational study was carried out in the Departments of Clinical Chemistry and Medical Microbiology, Al Razi Hospital, Kuwait, one of the major orthopedic hospitals with 210 beds. Diabetic patients who underwent surgical orthopedic procedures in Al Razi Hospital from January 2006 to December 2007 were identified from the patients' medical records (laboratory request forms, log books and patient files). These forms provided demographic and clinical information on patients including age, gender, relevant clinical data, $\mathrm{HbA}_{1 \mathrm{c}}$ values, type of specimen and data from microbiological reports, including species of the isolated pathogen. In addition, clinical data, type of surgery, length of operation and information on postoperative complications were obtained from the patients' files.

\section{Patient Selection}

Patients included in our study had established DM (regardless of diabetes subtype) and had received antidiabetic treatment for at least 1 year before surgery. The presence of DM before hospital admission was documented in the admission note, emergency room note, admission orders and discharge summary or by prescription of antidiabetic medications in the admission orders. Patients recently diagnosed as having DM, impaired glucose tolerance or who were already on antibiotics were excluded from the study.

\section{Laboratory Data}

$\mathrm{HbA}_{1 \mathrm{c}}$ levels recorded within 1 month prior to surgery were used in the study. The degree of glycemic control was assessed by $\mathrm{HbA}_{1 \mathrm{c}}$ values more or less than $7 \%$ [13]. $\mathrm{HbA}_{1 \mathrm{c}}$ was determined immunoturbidimetrically using Cobas Integra 400 Plus [14].

For microbiological data, patients were classified as having a postoperative infection if any of the following infections developed after 48 h or later: surgical site infection (SSI), lower respiratory tract infection, urinary tract infection (UTI) or sepsis [15]. Patients' specimens (urine, pus or tissue, sputum, blood) were collected and cultured. The representative colonies were identified using the automated Vitek ID system (Bio-Mérieux Vitek Inc., Hazelwood, Mo., USA) and APIE20 (Bio-Mérieux Inc., Marcy l'Etoile, France). These tests were made and criteria for the results were assessed according to the manufacturer's instructions. In addition, Staphylococcus species isolates were identified by Gram's stain and the tube coagulation test.

\section{Outcome Measures}

All measures were defined according to Center for Disease Control and Prevention guidelines based on clinical and laboratory findings [15]. The measures were followed while the patient was in hospital after $48 \mathrm{~h}$ or later, or within 30 days after surgery with purulent drainage at the site of incision.

\section{Statistical Analysis}

All data management and analysis were done using SPSS version 15 [16]. The descriptive statistics, including frequencies, were used to describe the study findings. The association between two discrete variables was tested by $\chi^{2}$ analysis; $p<0.05$ was considered significant. Logistic regression was also used, including the factors that were statistically significant at $p<0.05$ in the unadjusted analyses to produce adjusted results showing the independent impact of each factor on the outcome. Odds ratios and their corresponding confidence intervals and $\mathrm{p}$ values were also calculated.

\section{Results}

\section{Study Population and Patient Characteristics}

During the study period, a total of 318 diabetic patients were assessed. Patients were predominantly male $(175,55.0 \%)$ with a median age of 58 years (range: $6-60)$; the median operative duration was $120 \mathrm{~min}$. The range of recorded $\mathrm{HbA}_{1 \mathrm{c}}$ levels was $4.9-15.5 \%$ with a median level of $8.5 \%$. The majority of surgical operations were peripheral musculoskeletal (192; 60.4\%). Ninety (28.3\%) patients developed postoperative infectious complications (table 1).

\section{Postoperative Infectious Complications}

The distribution of total postoperative infectious complications according to a breaking point of $\mathrm{HbA}_{1 \mathrm{c}}<7 \%$ versus $\geq 7 \%$ is listed in table 2 . There is a significant relationship between the occurrence of complications and 
a high level of $\mathrm{HbA}_{1 \mathrm{c}}(\mathrm{p}<0.05)$. Of the 90 patients who developed complications, 72 developed 1 type and the remaining 18 developed 2 types, making a total of 108 postoperative complications.

The distribution of postoperative infectious complications according to a breaking point of $\mathrm{HbA}_{1 \mathrm{c}}<7 \%$ versus $\geq 7 \%$ is listed in table 3 . Urinary tract infectious complications showed a highly significant difference between the two $\mathrm{HbA}_{1 \mathrm{c}}$ groups $(\mathrm{p}<0.0001)$, while differences for the other complications (SSI, lower respiratory tract infection or sepsis) were not significant ( $p>0.05)$.

\section{Bacterial Isolates}

One hundred and eight specimens were subjected to bacteriological cultures yielding 140 bacterial isolates. Of the 108 specimens, $78(72.22 \%)$ had single isolates while $30(27.77 \%)$ had mixed isolates. The numbers of all types of isolated organisms were higher in the group with $\mathrm{HbA}_{1 \mathrm{c}} \geq 7 \%$. The distributions of uropathogens and pathogens isolated from patients with SSI are shown in table $4 \mathrm{~A}$ and $\mathrm{B}$, respectively. Among the 60 urinary specimens, Escherichia coli (27\%) was the most predominant pathogen followed by Klebsiella pneumoniae (20\%), Pseudomonas aeruginosa (13\%) and Enterococcus faecalis (12\%). Of the 60 inpatients with SSI, the most commonly isolated organisms were Staphylococcus aureus (23\%), Staphylococcus epidermidis (20\%), P. aeruginosa (12\%) and Enterobacter cloacae (10\%).

\section{Preoperative Variables and Postoperative Infectious \\ Complications}

The percentages of patients with infectious complications according to sociodemographic characteristics of the study populations are listed in table 5 . Factors associated with higher infectious risk included: $\mathrm{HbA}_{1 c}$, age and open type of surgery $(p<0.05)$, whereas sex, nationality and operation length had no significant impact on out- come. The significant variables in the unadjusted analysis were then entered into a multiple logistic regression model.

In this analysis, the type of operation was not a significant risk factor for postoperative infection, whereas age (odds ratio, 1.03; 95\% confidence interval, 1.02-1.08) and $\mathrm{HbA}_{1 \mathrm{c}}$ levels (odds ratio, 2.51; 95\% confidence interval, 1.20-2.89) continued to be significant.

Table 1. Sociodemographic characteristics of the studied population $(\mathrm{n}=318)$

\begin{tabular}{lc}
\hline Variable & Number (\%) \\
\hline Sex & \\
$\quad$ Male & $175(55.0)$ \\
Female & $143(45.0)$ \\
Nationality & \\
$\quad$ Kuwaiti & $170(53.5)$ \\
$\quad$ Non-Kuwaiti & $148(46.5)$ \\
Type of surgery & \\
Open & $29(9.1)$ \\
$\quad$ Closed & \\
$\quad$ Spine & $40(12.6)$ \\
$\quad$ Pelvic & $20(6.3)$ \\
$\quad$ Arthroplasty & $37(11.6)$ \\
$\quad$ Peripheral musculoskeletal & $192(60.4)$ \\
Operation length & $139(43.7)$ \\
$\quad<120$ min & $179(56.3)$ \\
$\geq 120$ min & \\
HbA & \\
Median, \% & $8.5(\mathrm{NA})$ \\
Range, \% & $4.9-15.5(\mathrm{NA})$ \\
$<7 \%$ & $80(25.2)$ \\
$\geq 7 \%$ & $238(74.8)$ \\
Postoperative complications & $228(71.7)$ \\
Absent & $90(28.3)$ \\
Present &
\end{tabular}

NA $=$ Not applicable

Table 2. Distribution of studied patients according to level of $\mathrm{HbA}_{1 \mathrm{c}}$ and postoperative complications

\begin{tabular}{|c|c|c|c|c|c|c|c|}
\hline \multirow[t]{2}{*}{ Postoperative complications } & \multicolumn{2}{|c|}{$\begin{array}{l}\text { Patients with } \mathrm{HbA}_{1 \mathrm{c}}<7 \% \\
(\mathrm{n}=80)\end{array}$} & \multicolumn{2}{|c|}{$\begin{array}{l}\text { Patients with } \mathrm{HbA}_{1 \mathrm{c}} \geq 7 \% \\
(\mathrm{n}=238)\end{array}$} & \multicolumn{2}{|c|}{$\begin{array}{l}\text { Total patients } \\
(\mathrm{n}=318)\end{array}$} & \multirow[t]{2}{*}{$\mathrm{p}$ value } \\
\hline & $\mathrm{n}$ & $\%$ & $\mathrm{n}$ & $\%$ & $\mathrm{n}$ & $\%$ & \\
\hline Absent & 66 & 82.5 & 162 & 68.10 & 228 & 71.70 & \multirow{2}{*}{$<0.01$} \\
\hline Present & 14 & 17.5 & 76 & 31.9 & 90 & 28.30 & \\
\hline One complication & 10 & 12.5 & 62 & 26.0 & 72 & 22.64 & $>0.05$ \\
\hline
\end{tabular}


Table 3. Distribution of types of postoperative complications according to glycemic control of the operated patients

\begin{tabular}{|c|c|c|c|c|c|c|}
\hline \multirow{2}{*}{$\begin{array}{l}\text { Type of } \\
\text { infections }\end{array}$} & \multirow[t]{2}{*}{ Total } & \multicolumn{2}{|c|}{$\mathrm{HbA}_{1 \mathrm{c}}<7 \%$} & \multicolumn{2}{|c|}{$\mathrm{HbA}_{1 \mathrm{c}} \geq 7 \%$} & \multirow[t]{2}{*}{$\mathrm{p}$ value } \\
\hline & & $\mathrm{n}$ & $\%$ & $\mathrm{n}$ & $\%$ & \\
\hline \multicolumn{7}{|l|}{ UTI } \\
\hline Absent & 272 & 76 & 27.94 & 196 & 72.06 & \multirow[t]{2}{*}{$<0.0001$} \\
\hline Present & 46 & 4 & 8.7 & 42 & 91.30 & \\
\hline \multicolumn{7}{|l|}{ SSI } \\
\hline Absent & 275 & 70 & 25.45 & 205 & 74.55 & \multirow[t]{2}{*}{$>0.05$} \\
\hline Present & 43 & 10 & 23.26 & 33 & 76.74 & \\
\hline \multicolumn{7}{|l|}{ LRTI } \\
\hline Absent & 303 & 78 & 25.74 & 225 & 74.26 & \multirow[t]{2}{*}{$>0.05$} \\
\hline Present & 15 & 2 & 13.33 & 13 & 86.67 & \\
\hline \multicolumn{7}{|l|}{ Sepsis } \\
\hline Absent & 314 & 78 & 24.84 & 236 & 75.16 & \multirow[t]{2}{*}{$>0.05$} \\
\hline Present & 4 & 2 & 50.00 & 2 & 50.00 & \\
\hline
\end{tabular}

LRTI $=$ Lower respiratory tract infection.

Table 4A. Prevalence of predominant uropathogen isolated from urine of post-operative patients

\begin{tabular}{lrlr}
\hline Organisms & \multirow{2}{*}{$\begin{array}{l}\text { Total } \\
(\mathrm{n}=60)\end{array}$} & \multicolumn{2}{l}{$\mathrm{HbA}_{1 \mathrm{c}}, \%$} \\
\cline { 3 - 4 } & & $<7$ & $\geq 7$ \\
\hline Escherchia coli & $16(27 \%)$ & 1 & 15 \\
Klebsiella pneumoniae & $12(20 \%)$ & 2 & 10 \\
Pseudomonas aerugenosa & $8(13 \%)$ & 0 & 8 \\
Enterococus faecalis & $7(12 \%)$ & 0 & 7 \\
Others & $17(28 \%)$ & 1 & 16 \\
\hline
\end{tabular}

Table 4B. Prevalence of predominant pathogen isolated from SSI of post-operative patients

\begin{tabular}{lrlr}
\hline Organisms & \multirow{2}{*}{$\begin{array}{l}\text { Total } \\
(\mathrm{n}=60)\end{array}$} & \multicolumn{2}{l}{$\mathrm{HbA}_{1 \mathrm{c}}, \%$} \\
\cline { 3 - 4 } & & $<7$ & $\geq 7$ \\
\hline Staphylococcus aureus & $14(23 \%)$ & 5 & 9 \\
Staphylococcus epidermidis & $12(20 \%)$ & 2 & 10 \\
Pseudomonas aerugenosa & $7(12 \%)$ & 2 & 5 \\
Enterobacter cloacea & $6(10 \%)$ & 0 & 6 \\
Others & $21(35 \%)$ & 2 & 19 \\
\hline
\end{tabular}

\section{Discussion}

Using the American Diabetes Association target for $\mathrm{HbA}_{1 \mathrm{c}}$ levels of less than 7\% to define good glycemic control [13], our data showed that good preoperative glyce-
Table 5. Preoperative variables and postoperative infectious complications

\begin{tabular}{|c|c|c|c|}
\hline Variable & $\begin{array}{l}\text { All patients } \\
(\mathrm{n}=318)\end{array}$ & $\begin{array}{l}\text { Percent with } \\
\text { infections }\end{array}$ & $\mathrm{p}$ value \\
\hline \multicolumn{4}{|l|}{ Age } \\
\hline$<58$ years & 158 & 22.8 & \multirow[t]{2}{*}{$<0.03$} \\
\hline$>58$ years & 160 & 33.8 & \\
\hline \multicolumn{4}{|l|}{ Sex } \\
\hline Male & 175 & 28.0 & \multirow[t]{2}{*}{$>0.05$} \\
\hline Female & 143 & 28.7 & \\
\hline \multicolumn{4}{|l|}{ Nationality } \\
\hline Kuwaiti & 170 & 28.2 & \multirow[t]{2}{*}{$>0.05$} \\
\hline Non-Kuwaiti & 148 & 28.4 & \\
\hline \multicolumn{4}{|l|}{ Type of surgery } \\
\hline Open & 29 & 55.2 & \\
\hline \multicolumn{4}{|l|}{ Closed } \\
\hline Spine & 40 & 27.5 & \multirow[t]{5}{*}{$<0.002$} \\
\hline Pelvic & 20 & 25.0 & \\
\hline Arthroplasty & 37 & 45.9 & \\
\hline Peripheral & & & \\
\hline musculoskeletal & 192 & 21.4 & \\
\hline \multicolumn{4}{|l|}{ Operation length } \\
\hline$<120 \mathrm{~min}$ & 139 & 23 & \multirow[t]{2}{*}{$>0.05$} \\
\hline$\geq 120 \mathrm{~min}$ & 179 & 32.4 & \\
\hline \multicolumn{4}{|l|}{$\mathrm{HbA}_{1 \mathrm{c}}$} \\
\hline$<7 \%$ & 80 & 17.5 & \multirow[t]{2}{*}{$<0.01$} \\
\hline$\geq 7 \%$ & 238 & 31.9 & \\
\hline
\end{tabular}

mic control leads to a significantly lower risk of postoperative infections.

Wilson et al. [17] and Bishop et al. [18] had explored the question of whether or not long-term control of blood glucose affected the occurrence of postoperative infections. Each of these had been limited to the study of SSI in a group of patients undergoing a specific type of operation $[17,18]$. Our selected patients underwent a variety of orthopedic surgical procedures and were evaluated for all potential infectious complications, not just SSI.

There was a very significantly lower risk of postoperative infection in the well-controlled diabetic group $\left(\mathrm{HbA}_{1 \mathrm{c}}\right.$ $<7 \%)$ compared to the uncontrolled group $\left(\mathrm{HbA}_{1 \mathrm{c}} \geq 7 \%\right)$ regarding the occurrence of UTI $(\mathrm{p}<0.01)$. Our data confirmed the previous study reported by Dronge et al. [19].

Regarding UTI, our data showed a significantly higher percentage of postoperative UTI in patients with uncontrolled diabetes compared to those with controlled diabetes $(\mathrm{p}<0.01)$. Yang et al. [20] studied 86 diabetic patients who underwent total knee arthroplasty; $15 \%$ developed UTI within 1 month postoperatively. Unfortu- 
nately, they did not examine the relationship between UTI and $\mathrm{HbA}_{1 \mathrm{c}} \geq 7 \%$ [20].

Regarding the occurrence of postoperative pneumonia and sepsis, our data showed no significant difference between controlled and uncontrolled diabetic subjects ( $\mathrm{p}>$ 0.05 ). This may be due to the low number of subjects with these complications in our study, resulting in low statistical power. Further study examining larger numbers of patients with these complications is recommended.

No significant difference for the occurrence of SSI was found between our two postoperative groups ( $p>0.05$ ), similar to the previous findings of Wilson et al. [17], who reported no association between $\mathrm{HbA}_{1 \mathrm{c}} \geq 11.5 \%$ and SSI. However, our data were not in agreement with those of Bishop et al. [18], who used a cutoff level of $\mathrm{HbA}_{1 \mathrm{c}}>11.5 \%$, thereby placing all diabetic patients with $\mathrm{HbA}_{1 \mathrm{c}}$ between 7 and $11.5 \%$ in the well-controlled group, which is not consistent with present recommendations of the American Diabetes Association [13].

Glycemic control is a risk factor for the occurrence of postoperative infection in diabetics, but other factors must also be considered, including smoking, body mass index, alcohol abuse, immune status of the patient, steroid therapy, nutrition status, type of operation (elective or emergency), duration of operation, number of medical personnel during operation, estimated blood loss, use of allograft or instrumentation, drainage and its duration and American Society of Anesthesiologists preoperative assessment score [21,22].

This study has highlighted two microbiological issues. First, that $S$. aureus remains the most important microorganism responsible for postoperative wound infection in our orthopedic hospital, accounting for $23 \%$, thereby confirming a previous study [23]. Secondly, E. coli continues to be the most common uropathogen of UTI (27\%), as this finding also confirmed that of a previous study in Kuwait that examined both hospital- and communityacquired UTI [24] and those of Dronge et al. [19].
There are two primary complications for diabetic patients: macrovascular and microvascular diseases. Plaques easily form in the circulatory system of patients with macrovascular disease, producing a high carriage rate of organisms. In patients with microangiopathy, subsequent decreased nutrition and oxygen delivery to peripheral tissues can reduce the body's ability to resist infection [25]. Poor blood sugar control will impair the leukocytic ability for chemotaxis $[26,27]$, adherence [28], phagocytosis and intracellular elimination of microorganisms [29].

Neither chronic complications nor the type of diabetes therapy was examined in the study. The Diabetes Control and Complications Trial Research Group proved that intensively monitored insulin therapy reduces the risk of retinopathy, albuminuria, microalbuminuria and neuropathy when compared to conventional therapy in type I diabetes [30]. Again, the United Kingdom Prospective Diabetes Study showed that patients with type $2 \mathrm{DM}$ who received intensive glucose therapy had a lower risk of microvascular complications than did those receiving conventional dietary therapy [31]. Other factors that are known to be associated with postoperative infection were not included in the study, i.e. wound classification, urgency of cases, smoking, nutritional status and blood loss.

\section{Conclusion}

Our study confirmed an association between tight preoperative glucose control indicated by $\mathrm{HbA}_{1 \mathrm{c}}$ levels less than $7 \%$ and a decreased risk of postoperative infections. Ideally, preoperative blood sugar should be controlled by conservative treatment prior to elective surgery. If conservative treatment fails and surgery is indicated, prophylaxis by antibiotics with preoperative patient preparation, proficient surgical technique and postoperative wound care is recommended for uncontrolled diabetics subjected to urgent surgery.

\section{References}

1 Nadeem SR: Microbiology of diabetic foot infections in Malaysia: a retrospective study of 194 cases. J Microbiol Immunol Infect 2007;40:39-44.

$>2$ Abdella N, Akanji AO, Mojiminiyi OA, Al Assoussi A, Moussa M: Relation of serum total sialic acid concentrations with diabetic complications and cardiovascular risk factors in Kuwaiti type 2 diabetic patients. Diabetes Res Clin Pract 1998;42:187-196.
3 Liao JC, Chen WJ, Chen LH, Niu CC: Postoperative wound infection rates after posterior instrumented spinal surgery in diabetic patients. Chang Gung Med J 2006;29:480485.

4 Zerr KJ, Furnary AP, Grunkemeier GL, Bookin S, Kanhere V, Starr A: Glucose control lowers the risk of wound infection in diabetics after open heart operations. Ann Thorac Surg 1997;63:356-361.
5 Browne WJ, Cook C, Pietrobon R, Bethel MA, Richardson WJ: Diabetes and early postoperative outcomes following lumbar fusion. Spine 2007;32:2214-2219.

-6 Di Palo S, Ferrari G, Castoldi R, Fiacco E, Cristallo M, Staudacher C, Chiesa R, Di Carlo V: Surgical septic complications in diabetic patients. Acta Diabetol Lat 1988;25:4954. 
7 Wimmer C, Gluch H, Franzreb M, Ogon M: Predisposing factors for infection in spine surgery: a survey of 850 spinal procedures. J Spinal Disord 1998;11:124-128.

-8 Simpson JM, Silveri CP, Balderston RA, Simeone FA, An HS: The results of operations on the lumbar spine in patients who have diabetes mellitus. J Bone Joint Surg Am 1993; 75:1823-1829.

-9 O'Sullivan CJ, Hynes N, Mahendran B, Andrews EJ, Avalos G, Tawfik S, Lowery A: $\left(\mathrm{HbA}_{1 \mathrm{c}}\right)$ in non-diabetic and diabetic vascular patients: is $\mathrm{HbA}_{1 \mathrm{c}}$ an independent risk factor and predictor of adverse outcome? Eur J Vasc Endovasc Surg 2006;32:188-197.

-10 Rohlfing CL, Wiedmeyer HM, Little RR, England JD, Tennill A, Goldstein DE: Defining the relationship between plasma glucose and $\mathrm{HbA}_{1 \mathrm{c}}$ : analysis of glucose profiles and $\mathrm{HbA}_{1 \mathrm{c}}$ in diabetes control and complications trial. Diabetes Care 2002;25:275-278.

11 Diabetes Control and Complications Trial Research Group: The effect of intensive treatment of diabetes on the development and progression of long-term complications in insulin dependent diabetes mellitus. $\mathrm{N}$ Engl J Med 1993;329:977-986.

12 UK Prospective Diabetes Study Group: Intensive blood-glucose control with sulphonylureas or insulin compared with conventional treatment and risk of complications in patients with type 2 diabetes (UKPDS 33). Lancet 1998;352:837-853.

13 American Diabetes Association: Standards of medical care in diabetes. Diabetes Care 2005;28(suppl):S4-S36.

14 Goldstein DE, Little RR, Lorenz RA, Malone JI, Nathan D, Peterson CM: Tests of glycemia in diabetes. Diabetes Care 1995;18:896-909.
15 Horan TC, Andrus M, Dudeck MA: CDC/ NHSN surveillance definition of health care-associated infection and criteria for specific types of infections in the acute care setting. Am J Infect Control 2008;36:309332.

16 SPSS for Windows, release 15.0.0. Chicago, SPSS Inc, 2006.

17 Wilson SK, Carson CC, Cleves MA, Delk JR: Quantifying risk of penile prosthesis infection with elevated glycosylated hemoglobin. J Urol 1998;159:1537-1539.

18 Bishop JR, Moul JW, Sihelnik SA, Peppas DS, Gormely TS, McLeod DG: Use of glycosylated hemoglobin to identify diabetics at high risk for penile periprosthetic infections. Urol 1992;147:386-388.

19 Dronge AS, Perkal MF, Kancir S, Concato J, Aslan M, Rosenthal RA: Long-term glycemic control and postoperative infectious complications. Arch Surg 2006;141:375-380.

20 Yang K, Yeo SJ, Lee BP, Lo NN: Total knee arthroplasty in diabetic patients: a study of 109 consecutive cases. J Arthroplasty 2001; 16:102-106.

21 Fang A, Hu SS, Endres N, Bradford DS: Risk factors for infection after spinal surgery. Spine 2005;30:1460-1465.

22 Maksimović J, Marković-Denić L, Bumbasirević M, Marinković J, Vlajinac H: Surgical site infections in orthopedic patients: prospective cohort study. Croat Med J 2008; 49:58-65.

23 Onche I, Adedeji O: Microbiology of postoperative wound infection in implant surgery. Niger J Surg Res 2004;6:37-40.
24 Al Sweih N, Jamal W, Rotimi VO: Spectrum and antibiotic resistance of uropathogen isolated from hospital and commuity patients with urinary tract infection in two large hospitals in Kuwait. Med Princ Pract 2005;14: 401-407.

25 Giardino I, Brownlee M: The biochemical basis of microvascular disease; in Pickup JC, Williams G (eds): Textbook of Diabetes, ed 2. Oxford, Blackwell Science, 1997, pp 42.0142.16 .

26 Mowat A, Baum J: Chemotaxis of polymorphonuclear leukocytes from patients with diabetes mellitus. N Engl J Med 1971;284: 621-627.

27 Delamaire M, Maugendre D, Moreno M, Le Goff MC, Allannic H, Genetet B: Impaired leukocyte functions in diabetic patients. Diabet Med 1997;14:29-34.

28 Bagdade JD, Stewart M, Walters E: Impaired granulocyte adherence: a reversible defect in host defense in patients with poorly controlled diabetes. Diabetes 1978;27:677-681.

29 Sima AA, O’Neill SJ, Naimark D, Yagihashi S, Klass D: Bacterial phagocytes and intracellular killing by alveolar macrophages in BB rats. Diabetes 1988;37:544-549.

30 Diabetes Control and Complications Trial Research Group: The effect of intensive treatment of diabetes on the development and progression of long-term complications in insulin-dependent diabetes mellitus. $\mathrm{N}$ Engl J Med 1993;329:977-986.

- 31 Holman RR, Paul SK, Bethel MA, Matthews DR, Neil HA: 10-year follow-up of intensive glucose control in type 2 diabetes. $\mathrm{N}$ Engl J Med 2008;359:1577-1589. 